41.

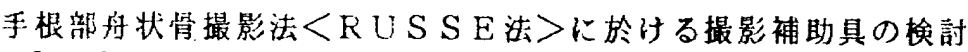

Development and Evaluation of a supporting device in Russe's method.

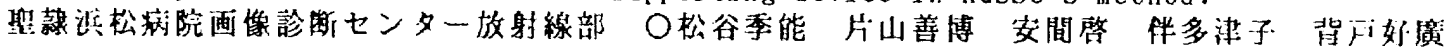

(目的）複雑な構造を持つ舟状骨の撮影に、当院ではＲＵＳＳＥ法による4方向撮影を取り入扎たが、この

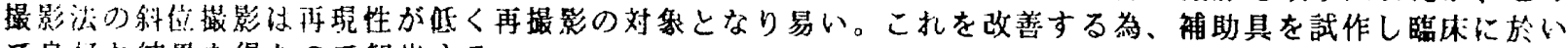
て良好な結果を得たので報告する。

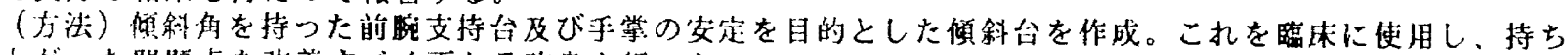
上がニた問題点を改善すべく更なる改良を行った。

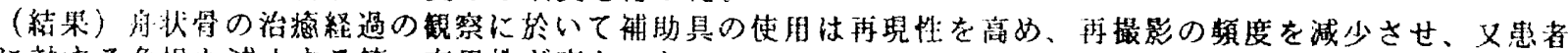
に対守る真担も減少する等、有用性が高かつた。

\title{
42. 足関節側位撮影における形態解剖学的検討
}

A study of the morphological anatomy as to lateral view of the ankle joint

立正佼成会附属佼成病院 放射線室 ○新里久仁子 葉山和弘 梅木智子 渡刃雅弘

目的：足関節側位撮影における整位不良による排除率は高く、完成されたと思われた整位論にはまだ問題がある。そ の理由は、足関節そのものに形態分類が存在するからであり、形態解剖学に沿って足関節側位撮影に関して比较検討 を行ったので報告する。

方法 : 部分整位論から見れば、内反足、外反足、直足を形態特性とし、その特性から整位諭を導き出すことが必要で あると思われる。

結果および結論：形態と体表目標の相関を求める場合、体表目標をアキレス腱約中央を通る体軸線と距炦関節面の成 す角度から形態分類を考察した。その相関についてはほぼ良好な相関を示していた。

43. $\mathrm{R}$ o s e n b e r g 法における基礎的検討

B a s i c s t ud $y$ of $R$ o s e n b e r g m e thod

東京大学医学部附属病院放射線部。野島任・俵紀行・阿部欣二

㮩関節撮影法のひとつであるRos e n b e r g 法におけるポシシションのセッティングに は目頃から大変苦労を要する。そこで我々は、ルーチン化の度合を高めるために、今回足の 大きさと位置に着目した新しいスケールを試作し、従来より行っている方法との此較检討を 施行した。

新しいスケールを使用することにより、ポジショニングに要する時間が改善された。それ に伴い、患者さんへの負担も低減したうえで術者自身の負担も軽くなったため、繰り返し撮 影する場面において両者共に好評を得た。

44. X線骨整計测写真に上万胎児体重の推定

Estination of fetal weight ith the use of head and vertebra size on cephalopelvinetry filn

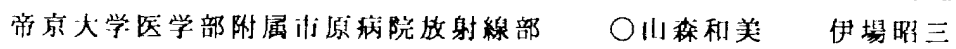

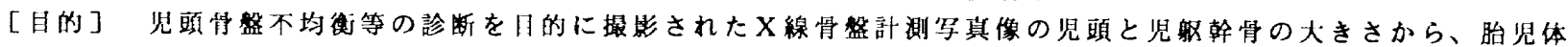
重の推定が可能であるか検討を行った。

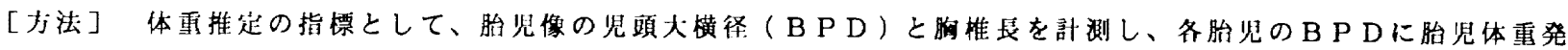
育曲線と B P D 標準発育曲線から求めた各在胎週の基準となる体重/B P Dを乗して基集体重を求めた。

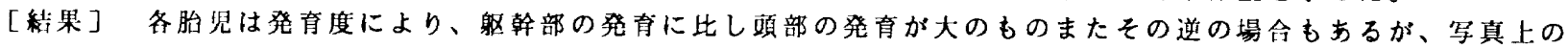
B P D と胸椎長の比から頭部と躯幹部の発有度補正を行うことによって、各推定体重做は出生体重值の土10\%以内の

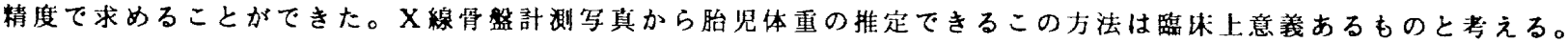

